\title{
Absorption spectroscopy of colored dissolved organic carbon in Georgia (USA) rivers: the impact of molecular size distribution
}

\author{
Yosef Z. YACOBI*, James J. ALBERTS ${ }^{1)}$, Monika TAKÁCS ${ }^{1)}$ and Michelle McELVAINE ${ }^{2)}$ \\ Israel Oceanographic and Limnological Research, Kinneret Limnological Laboratory, P.O.Box 447, Migdal 14950, Israel \\ ${ }^{1)}$ University of Georgia Marine Institute, Sapelo Island, GA 31327, USA \\ ${ }^{2)}$ Division of Marine and Environmental Systems, Florida Institute of Technology $150 \mathrm{~W}$. University Boulevard, Melbourne, FL \\ 32901, USA \\ *e-mail corresponding author: yzy@ocean.org.il
}

\begin{abstract}
Dissolved organic carbon (DOC) was collected in six rivers that transect the coastal plain of Georgia in July 1999 and February 2000. DOC concentrations ranged from 4.9 to $40.7 \mathrm{~g} \mathrm{~m}^{-3}$ and from 7.1 to $40.5 \mathrm{~g} \mathrm{~m}^{-3}$, respectively. The absorption coefficient at 440 $\mathrm{nm}$ was highly correlated with DOC concentration, suggesting that the optical parameter may be utilized for rapid estimation of DOC in these waters. The isolated DOC was separated into fractions of operationally defined molecular size, using an ultrafiltration technique that yielded three fractions: $<10$ ("small"), 10-50 ("medium") and >50 ("large") kilodalton. The smallest fraction was the most abundant ( $>50 \%)$ in 4 rivers in July and in all rivers in February, and considerably more abundant than in previous years. The wavelength-dependent absorption of the total DOC and its fractions showed approximately uniform shape of a curve declining exponentially with the increase of wavelength. The average slope of logarithmically transformed curves was 0.0151 and $0.0159 \mathrm{~nm}^{-1}$, for the material collected in July and February, respectively and showed a dependence on DOC molecular size. In unfractionated DOC samples, the mass-specific light absorption determined at $440 \mathrm{~nm}$ was on average $0.33 \mathrm{~m}^{2} \mathrm{~g}^{-1}$ in July, and $0.26 \mathrm{~m}^{2} \mathrm{~g}^{-1}$ in February. The mass-specific absorption coefficient in all fractions ranged between 0.085 and $1.347 \mathrm{~m}^{2} \mathrm{~g}^{-1}$ in July and between 0.085 and 1.877 $\mathrm{m}^{2} \mathrm{~g}^{-1}$ in February, and was positively correlated with the molecular size of the measured samples. The results of the reported study clearly suggest that the specific absorption coefficient of the yellow substance is an outcome of the relative contribution of its different size fractions.
\end{abstract}

Key words: absorption coefficient of DOC, humic substances, size fractions of DOC

\section{INTRODUCTION}

Most organic molecules dissolved in water lack optical activity in the visible range, and therefore appear colorless to the human eye. A prominent exception is that of humic substances, which strongly absorb in the blue range of the spectrum, and impart a yellowbrownish hue to water. Considering their color, those substances were called Gelbstoff (Kalle 1937 cf. Kalle 1966), yellow substance (Bricaud et al. 1981; DavisColley \& Vant 1987), aquatic humus (Zepp \& Schlotzhauer 1981 ) and gilvin (Kirk 1994). Humic substances strongly absorb solar energy in the UV range, therefore the concentration of those compounds, and their composition have a high potential of influence on the aquatic environment, either as direct moderators of the in-water light climate, or sources of carbon for the aquatic biota (e.g., Obernosterer et al. 2001). Humic substances also display chelating activity (e.g., Alberts et al. 1984), and thus are capable of altering the bioavailability and/or the toxicity of elements, with a potential to influence the development of organisms.

The decline of light absorption by colored dissolved organic carbon (DOC) in water from the UV wavelength range towards longer wavelengths in the visible range is best described by an exponential function.
Logarithmic transformation yields, therefore, almost a linear line, and at any point is linearly correlated with all other points (Bricaud et al. 1981). DOC absorption is often defined quantitatively as the value measured at $440 \mathrm{~nm}$, since that wavelength is located in the midpoint of the blue range peak of most plant pigments (Kirk 1994). The measured variability of DOC absorption at $440 \mathrm{~nm}$ varies over 3 orders of magnitude, with high values found in inland waters and the lowest in oligotrophic oceans (Kirk 1994). Attempts to translate the optical characteristic to concentrations were done only on a few occasions, and those attempts show that the specific absorption of different DOC sources varies considerably (Carder et al. 1989).

Humic substances are products of decomposition of plant material and comprise a large number of different molecules. A distinction is made between humic acid, and fulvic acid. The elemental composition of both groups is fairly similar, but they differ in their molecular weight range; humic acid is comprised of larger molecules than fulvic acid. The specific light absorption of humic acid is higher than that of fulvic acid, and the slope of the line characterizing a decline of absorption with increasing wavelength, is larger for fulvic than for humic acid (Carder et al. 1989). However, in aquatic systems the DOC contains a wide range of molecular 
sizes, even in acidic waters, so the operational definition is less reliable.

The rivers that transect the coastal plain of Georgia, and discharge water to the Atlantic Ocean drain 89,000 $\mathrm{km}^{2}$ of forested and agricultural uplands (NOAA 1985; Alexander et al. 1986). The concentration of DOC in those rivers ranges between approximately 5-40 $\mathrm{g} \mathrm{m}^{-3}$, which is ten times the concentration of particulate organic carbon (POC) (Alberts et al. 1990). For the most part, the rivers are colored by DOC, which is dominated by high molecular weight fractions (Alberts \& Filip 1994). In this study we sampled six rivers (five draining into the Atlantic Ocean and one which drains into the Gulf of Mexico). The DOC was isolated and separated into fractions of defined molecular size. The goal of this study was to define the optical characteristics of those fractions in terms of spectral behavior and their impact on the optical characteristics of the bulk colored DOC.

\section{MATERIAL AND METHODS}

Water samples (approximately 10 1) were collected in July 1999 and once again in February 2000, from the Savannah, Ogeechee, Altamaha, Satilla, and St. Marys rivers, which drain into the Atlantic Ocean and the Suwannee River at Fargo, Georgia, near its origin in the Okeefenokee Swamp. The Suwannee River drains into the Gulf of Mexico. The sampling locations of the rivers have previously been described (Alberts et al. 1984, Alberts \& Griffin 1996), as has the method of separation by ultrafiltration (Alberts \& Griffin 1996). Briefly, the samples were transported (within less than 6 hours) in opaque, plastic carboys to the University of Georgia Marine Institute (UGAMI), and stored for maximally 4 days in the dark at $4{ }^{\circ} \mathrm{C}$. Samples were filtered through $0.7 \mu \mathrm{m}$ glass fiber filters (Gelman $\mathrm{GF} / \mathrm{F}$, precombusted at $450{ }^{\circ} \mathrm{C}$ for 4 hours). The product obtained after the filtration is called "origin" samples throughout this paper. The DOC of the origin samples was fractionated by means of differential ultrafiltration in a stirred cell (Model 401, Amicon Corp.).

For ultrafiltration the cell was filled up to $400 \mathrm{ml}$, then the volume of the cell was reduced to $200 \mathrm{ml}$. We added $200 \mathrm{ml}$ of deionized water to fill the cell, and again reduced the volume to half. This procedure, of deionized water additions, was repeated three times for each of two ultrafilters (Amicon Corp., XM-50 and YM10). Ultrafiltration resulted in three molecular size fractions: <10 ("small"), 10-50 ("medium") and >50 ("large") kilodalton nominal molecular weight (NMW).

The concentration of DOC in the filtered origin water sample and in the fractions was determined by high temperature combustion (Model 500 TOC Analyzer, Shimadzu Corp.) following the method by Benner \& Hedges (1993).

Light attenuation of the samples was measured with a Perkin-Elmer Lambda 40 spectrophotometer, in a 1$\mathrm{cm}$-path-length quartz-glass cuvette over the range from 200 to $700 \mathrm{~nm}$. Considering the short light pathway, and the fact that samples were filtered through $0.7 \mu \mathrm{m}$ glass fiber filters, we assumed that scattering may be neglected as a factor causing light attenuation, and defined measurements as absorption. Readings were done against distilled water, and the absorption coefficient, a, was multiplied $\times 100$, to get the absorption value expressed as $\mathrm{m}^{-1}$. Absorption coefficient per mass unit of particles, specific absorption coefficient, $\mathrm{a}_{440} *$, was determined from the ratio of the calculated absorption coefficient at $440 \mathrm{~nm},\left(\mathrm{~m}^{-1}\right)$, to the DOC concentration $\left(\mathrm{g} \mathrm{m}^{-3}\right)$, following the procedure used previously by Carder et al. (1989), and its unit is $\mathrm{m}^{2} \cdot \mathrm{g}^{-1}$.

\section{RESULTS}

In July 1999 DOC concentrations ranged from 4.9 to $40.7 \mathrm{~g} \mathrm{~m}^{-3}$, and from 7.1 to $40.5 \mathrm{~g} \mathrm{~m}^{-3}$, in February 2000 . Percentage recovery of DOC after ultrafiltration ranged from $90-112 \%$, and $88-104 \%$, respectively (Tab. 1). This

Tab. 1. Dissolved organic carbon (DOC) concentrations in Georgia Rivers from July 1999 and February 2000. Absorption coefficient at $440 \mathrm{~nm}\left(\mathrm{a}_{440}\right)$ of the origin samples and the percentage contributed by the 3 size class fractions (see Material and Methods for size class definition).

\begin{tabular}{|c|c|c|c|c|c|c|}
\hline & \multirow{2}{*}{$\begin{array}{c}\text { DOC } \\
\left(\mathrm{g} \mathrm{m}^{-3}\right)\end{array}$} & \multirow{2}{*}{$\begin{array}{c}\mathrm{a}_{440} \\
\left(\mathrm{~m}^{-1}\right)\end{array}$} & \multicolumn{3}{|c|}{ Percent of fraction in total } & \multirow{2}{*}{$\begin{array}{c}\text { Recovery } \\
(\%)\end{array}$} \\
\hline & & & large & medium & small & \\
\hline \multicolumn{7}{|l|}{ July 1999} \\
\hline Suwannee & 40.7 & 10.05 & 25.3 & 31.2 & 37.4 & 93.9 \\
\hline Ogeechee & 35.0 & 10.19 & 24.0 & 24.1 & 41.5 & 90.0 \\
\hline Satilla & 24.2 & 7.04 & 16.7 & 30.2 & 59.5 & 106.4 \\
\hline St Marys & 20.0 & 6.65 & 14.2 & 35.2 & 50.4 & 99.8 \\
\hline Altamaha & 6.8 & 3.48 & 18.6 & 31.0 & 62.7 & 112.3 \\
\hline Savannah & 4.9 & 1.61 & 17.6 & 22.4 & 70.2 & 110.2 \\
\hline \multicolumn{7}{|c|}{ February 2000} \\
\hline Suwannee & 40.5 & 8.61 & 33.2 & 8.4 & 61.5 & 103.1 \\
\hline Ogeechee & 13.5 & 3.27 & 19.0 & 11.0 & 67.0 & 96.9 \\
\hline Satilla & 17.6 & 4.86 & 20.4 & 9.3 & 68.9 & 98.6 \\
\hline St Marys & 25.7 & 6.67 & 14.3 & 19.2 & 55.2 & 88.7 \\
\hline Altamaha & 7.1 & 2.60 & 12.8 & 10.1 & 70.6 & 93.5 \\
\hline Savannah & 7.8 & 1.87 & 10.4 & 9.8 & 83.8 & 104.0 \\
\hline
\end{tabular}


range is acceptable given the number of manipulations involved in the ultrafiltration process. In most cases in July 1999, and in all cases in February 2000, the majority of the DOC $(>50 \%)$ was in the smallest size fraction (Tab. 1). In all comparisons between July samples and February samples, the proportion of the small class was greater in February, by a factor that ranged from 1.10 to 1.64 . In July the medium fraction contributed higher proportion to DOC than the large fraction in 5 out of 6 cases. In February, on the other hand, the contribution of the large fraction was higher than that of the medium fraction in 5 out of 6 cases.
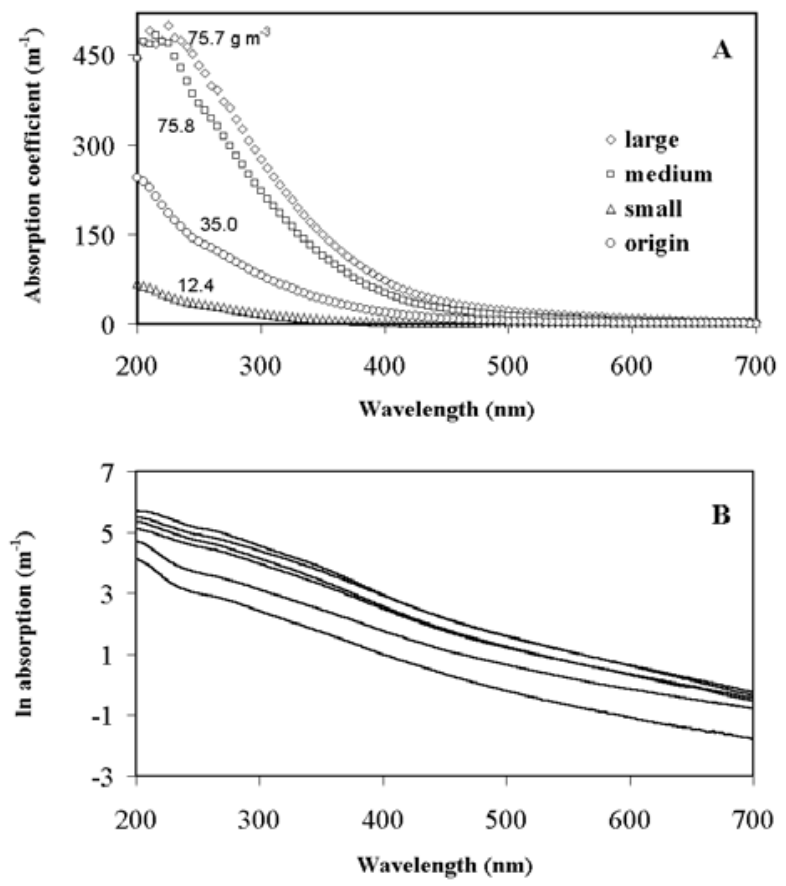

Fig. 1. Absorption coefficient spectra of dissolved organic carbon (DOC). A) Comparison of the origin and three molecular size fractions isolated from Ogeechee River samples in July 1999. The concentration of DOC $\left(\mathrm{g} \mathrm{m}^{-3}\right)$ is indicated in each case; B) Ln transformed absorption coefficient spectra of the origin samples of the six rivers in the study. Measurements of the samples taken in July 1999. The order of presentation, from top to bottom, is: Suwannee (40.7), Ogeechee (35.0), Satilla (24.2), St Marys (20.0), Altamaha (6.8), Savannah (4.9). The number in parentheses indicates the concentration of DOC $\left(\mathrm{g} \mathrm{m}^{-3}\right)$ in each sample.

The spectra of light absorption by DOC assumed the same basic pattern of monotonous decline with increase of wavelength, with a small exception in the range from 200 to approximately $230 \mathrm{~nm}$ regardless of the molecular size fraction examined (Fig. 1A). There were also exceptions in the small fraction from two rivers, with a slight increase of the absorption coefficient in the domain from 650 to $700 \mathrm{~nm}$ (data not shown). Otherwise, the similarity among rivers was high. The absorption values of the entire measured range were ln trans- formed. The resulting line was not perfectly linear (Fig. 1B), therefore, a first derivative of the ln transformed data was calculated, to pinpoint the spectral range with minimal change of slope, for computation of the line parameters. It showed that in most samples, the slope in the range from 300 throughout $450 \mathrm{~nm}$ showed minimal variation. That was, therefore, the interval used for the calculation of the slope coefficient, S, of the total DOC and its fractions. The slope coefficient of the small fraction was larger than the slope coefficient of the medium fraction, and the slope coefficient of the medium fraction was on average larger than that of the large fraction (Tab. 2). In July, the variability of the large and small fraction was lower than that of the medium fraction, while in February the medium fraction showed the lowest variability. The correlation between DOC concentration and $\mathrm{S}$ in the different fractions was very low, and insignificant.

Light absorption coefficient at $440 \mathrm{~nm}\left(\mathrm{a}_{440}\right)$ in the origin samples ranged from 1.61 to $10.19 \mathrm{~m}^{-1}$ in July, and from 1.87 to $8.61 \mathrm{~m}^{-1}$ in February (Tab. 1). The linear correlation between DOC and $\mathrm{a}_{440}$ was positive and high (Fig. 2). The mass-specific absorption coefficient, $\mathrm{a}^{*}{ }_{440}$ spanned between 0.085 and $1.347 \mathrm{~m}^{2} \mathrm{~g}^{-1}$ in different fractions and was highest in the largest DOC fraction. The average $\mathrm{a}^{*}{ }_{440}$ value was smallest in the small fraction, and the $\mathrm{a}^{*}{ }_{440}$ value of the medium fraction was between those extremes, both in July 1999 and February 2000 (Tab. 3). In the origin samples the average of a* ${ }_{440}$ in July was $0.33 \mathrm{~m}^{2} \mathrm{~g}^{-1}$, and the only prominent exception was the value found for the Altamaha sample, i.e., $0.51 \mathrm{~m}^{2} \mathrm{~g}^{-1}$. In February, the average $\mathrm{a}^{*}{ }_{440}$ was $0.26 \mathrm{~m}^{2}$ $\mathrm{g}^{-1}$, and once again, an exceptionally high value was found for the Altamaha sample $\left(0.37 \mathrm{~m}^{2} \mathrm{~g}^{-1}\right)$. The variability of $\mathrm{a}_{440}$ in the medium and small fractions was comparable to that found in the origin, but in the large fraction the variability of specific absorption was much higher than in the origin samples (Tab. 3).

\section{DISCUSSION}

The dissolved component of aquatic environments is composed, by definition, of any molecule capable of passing through a given pore size. The cutoff size is mostly determined by the filter used, which enables the passage of many types of colloids and ions, obviously with variable size and inherent optical characteristics. The current study clearly demonstrated a relationship between molecular size of colored DOC and optical characteristics, and moreover showed that the optical traits revealed by the colored DOC reflect the additive effect of the different molecular structures it is composed of. A comparison of the measured specific absorption coefficient in the origin filtrate $(>0.7 \mu \mathrm{m})$, with the weighed average of the fractions showed a strong similarity (Fig. 3). The weighed average was $87-93 \%$ of the measured values in July 1999, and $98-116 \%$ in February 2000 . 
Tab. 2. Slope coefficients (S) of $\ln$ transformed data of light absorption in samples taken from coastal rivers in Georgia, in July 1999 and February 2000. $\mathrm{S}$ was calculated for the wavelength range from 300 to $450 \mathrm{~nm}$ in samples of the bulk DOC (origin), and 3 size class fractions (see Material and Methods for size class definition). In all cases, the correlation coefficient, $r^{2}$, of the calculated slope was $>0.99$. (av $=$ average; std $=$ standard deviation; $\mathrm{cv}=$ coefficient of variation).

\begin{tabular}{lcccc}
\hline Fraction & Large & Medium & Small & Origin \\
\cline { 2 - 5 } & \multicolumn{2}{c}{$\left(\mathrm{S}, \mathrm{nm}^{-1}\right)$} \\
\hline July 1999 & 0.0146 & 0.0175 & 0.0209 & 0.0166 \\
Suwannee & 0.0139 & 0.0152 & 0.0186 & 0.0152 \\
Ogeechee & 0.0150 & 0.0142 & 0.0188 & 0.0160 \\
Satilla & 0.0149 & 0.0136 & 0.0178 & 0.0151 \\
St Marys & 0.0149 & 0.0114 & 0.0189 & 0.0135 \\
Altamaha & 0.0115 & 0.0139 & 0.0163 & 0.0140 \\
Savannah & 0.0141 & 0.0143 & 0.0186 & 0.0151 \\
av & 0.00135 & 0.00201 & 0.00151 & 0.00117 \\
std & 9.6 & 14.0 & 8.1 & 7.8 \\
cv & & & & \\
February 2000 & 0.0154 & 0.0175 & 0.0201 & 0.0172 \\
Suwannee & 0.0136 & 0.0164 & 0.0169 & 0.0160 \\
Ogeechee & 0.0130 & 0.0157 & 0.0175 & 0.0162 \\
Satilla & 0.0140 & 0.0156 & 0.0181 & 0.0163 \\
St Marys & 0.0108 & 0.0151 & 0.0148 & 0.0142 \\
Altamaha & 0.0116 & 0.0159 & 0.0169 & 0.0156 \\
Savannah & 0.0131 & 0.0160 & 0.0174 & 0.0159 \\
av & 0.00167 & 0.00083 & 0.00173 & 0.00099 \\
std & 12.8 & 5.2 & 10.0 & 6.2 \\
cv & & & & \\
\hline
\end{tabular}

Comparison of the light absorption coefficient at 440 $\mathrm{nm}$ from this study with data from other sources (Dekker 1993; Kirk 1994; Laurion et al. 2000) showed that the optical activity of yellow substance in Georgia rivers is among the highest in world water bodies. In the current study most of the DOC was found was in the small fractions ( $<10$ kilodalton). The relatively low proportion in the large and medium fractions (Tab. 1) was in contest to previous studies in Georgia coastal rivers, which showed that the larger fractions dominated the bulk DOC (Alberts et al. 1984; Alberts \& Filip 1994; Alberts \& Griffin 1996).

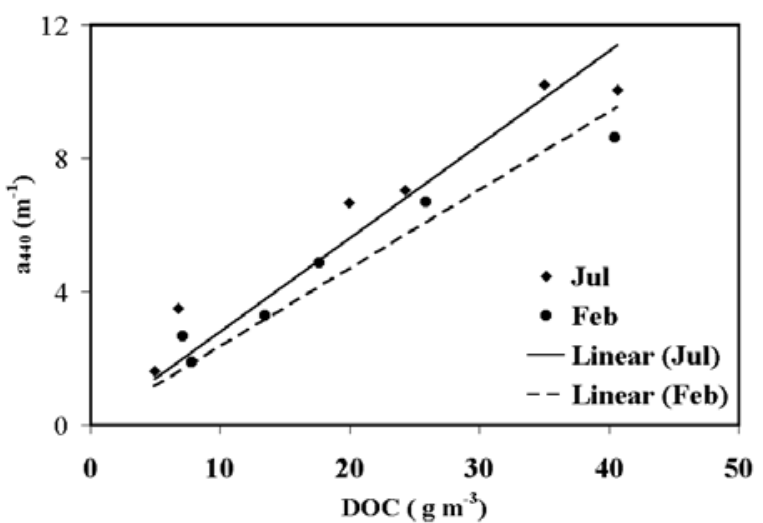

Fig. 2. A plot of the absorption coefficient at $440 \mathrm{~nm}$ versus DOC concentration in the origin samples. The relationship between the two parameters was: $y=0.2796 x\left(r^{2}=0.9051, n=\right.$ $6, \mathrm{p}<0.0007)$ in July 1999, and $\mathrm{y}=0.2352 \times\left(\mathrm{r}^{2}=0.9210, \mathrm{n}=\right.$ $6, \mathrm{p}<0.0005)$ in February 2000.
The logarithmic transformation of the absorption coefficient function of colored DOM did not result in a perfectly linear line in this study, as it was not absolutely linear in previous studies (Bricaud et al. 1981; Davis-Colley \& Vant 1987; Carder et al. 1989; Dekker 1993; Mopper et al. 1996). The assumption that the deviation from linearity is caused by variability of the constituents of yellow substance (Dekker 1993) hardly applies, as the curvature seems to follow a similar pattern in all fractions (Fig. 1A). The deviation from linearity underlines the need of cautious choice of the portion taken for the calculation of S - the slope coefficient of the function. Our value calculated for the interval from 300 to $450 \mathrm{~nm}, 0.015-0.016 \mathrm{~m}^{-1}$, was within the range previously reported for other freshwater and estuarine DOC (see compilation in Dekker 1993; Blough et al. 1993; Laurion et al. 2000), but were lower than the values found in the opened sea (Green \& Blough 1994; Ferrari \& Dowell 1998; Stedmon et al. 2000). The average $\mathrm{S}$ value found in our study is approximately an average between $\mathrm{S}$ values calculated by Carder et al. (1989) for fulvic acid and humic acid, isolated from sea-water in the Gulf of Mexico.

Carder et al. (1989) and Green \& Blough (1994) found that fulvic acid has higher $\mathrm{S}$ than humic acid. Given the domination of the small fraction in our samples, we assume that fulvic acid constituted a higher proportion of yellow substance than humic acid. Fulvic acid was also found to be more abundant than humic acid in yellow substance in productive freshwater bod- 
Tab. 3. Mass-specific absorption at $440 \mathrm{~nm}\left(\mathrm{a}^{*}{ }_{440}, \mathrm{~m}^{2} \mathrm{~g}^{-1}\right)$ in samples in the bulk DOC (origin), and 3 size class fractions (see Material and Methods for size class definition) taken from coastal rivers in Georgia, in July 1999 and February 2000. (av = average; $s t d=$ standard deviation; $\mathrm{cv}=$ coefficient of variation).

\begin{tabular}{lcccc}
\hline Fraction & Large & Medium & Small & Origin \\
\hline July 1999 & & & & \\
St Marys & 0.612 & 0.400 & 0.152 & 0.333 \\
Ogeechee & 0.550 & 0.369 & 0.112 & 0.291 \\
Satilla & 0.500 & 0.369 & 0.128 & 0.291 \\
Savannah & 0.811 & 0.311 & 0.124 & 0.324 \\
Suwannee & 0.438 & 0.246 & 0.085 & 0.247 \\
Altamaha & 1.347 & 0.400 & 0.112 & 0.513 \\
av & 0.710 & 0.349 & 0.119 & 0.333 \\
std & 0.337 & 0.060 & 0.022 & 0.093 \\
cv & 47.5 & 7.2 & 18.7 & 28.0 \\
February 2000 & & & & \\
St Marys & 0.541 & 0.402 & 0.152 & 0.258 \\
Ogeechee & 0.525 & 0.265 & 0.112 & 0.243 \\
Satilla & 0.581 & 0.310 & 0.128 & 0.276 \\
Savannah & 1.396 & 0.244 & 0.124 & 0.238 \\
Suwannee & 0.391 & 0.217 & 0.085 & 0.213 \\
Altamaha & 1.877 & 0.289 & 0.112 & 0.374 \\
av & 0.885 & 0.288 & 0.119 & 0.262 \\
std & 0.605 & 0.065 & 0.022 & 0.056 \\
cv & 68.3 & 22.5 & 26.9 & 21.1 \\
\hline
\end{tabular}

ies (Zepp \& Schlotzhauer 1981; Visser 1984; de Haan $\&$ de Boer 1986), as it is in the opened sea. In the marine environment, bacterial activity was assumed to be the factor for the decrease in S (Blough et al. 1993), and it is highly probable that bacterial activity in freshwater is causing decrease in the proportion of large molecules of DOC in inland productive water.

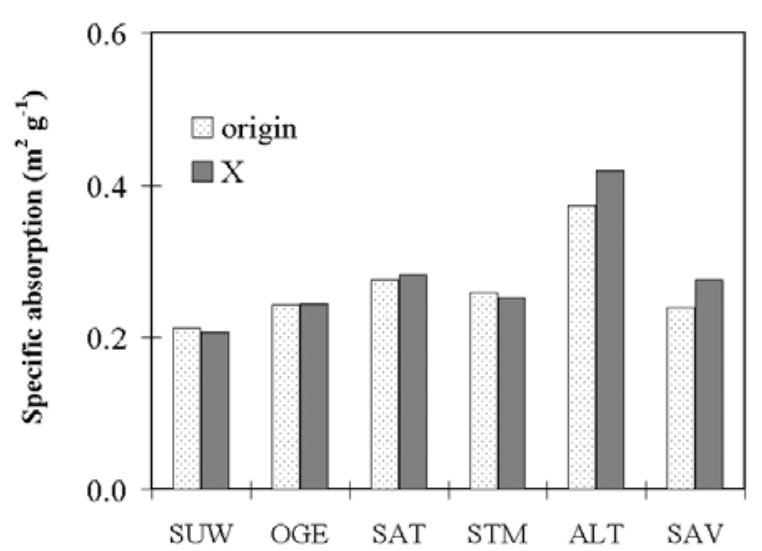

Fig. 3. Comparison of measured specific absorption coefficient of DOC of origin samples (filtrates passing $0.7 \mu \mathrm{m}$ ), with the weighed average of the fractions, in each sample (x). The presented data are from February 2000. SUW = Suwannee; OGE $=$ Ogeechee; SAT $=$ Satilla; STM $=$ St Marys; ALT $=$ Altamaha $; \mathrm{SAV}=$ Savannah.

Despite the similarity of spectral characteristics of all fractions studied, the mass-specific optical activity widely ranged. The mass-specific absorption values at
$440 \mathrm{~nm}, \mathrm{a}^{*}{ }_{440}$, of the origin samples in our study, were within the range of 0.162 and $0.407 \mathrm{~m}^{2} \mathrm{~g}^{-1}$ found for lakes in the Netherlands (Dekker 1993). The only exception was the extreme value of $0.513 \mathrm{~m}^{2} \mathrm{~g}^{-1}$ found in Altamaha, in July. In July the average $\mathrm{a}^{*}{ }_{440}$ was higher than in February (Tab. 3) and the slope of $a_{440}$ versus DOC, was also higher (Fig. 2).

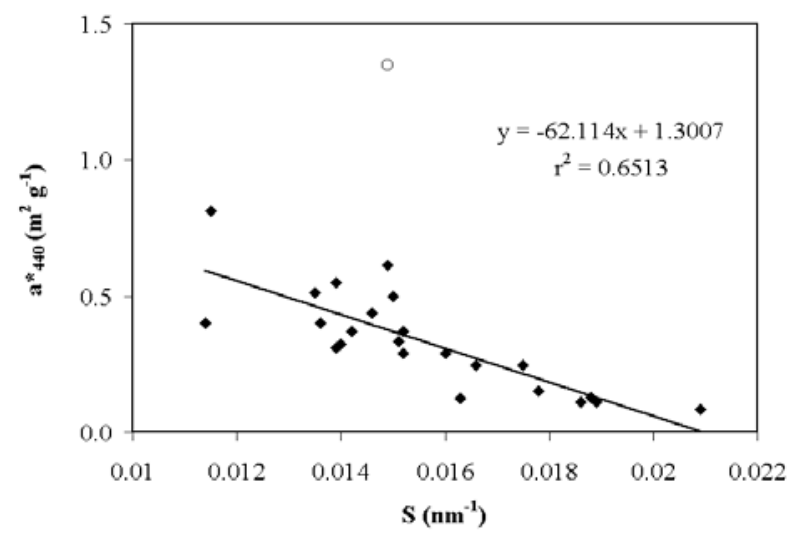

Fig. 4. A plot of slope coefficient, S, versus specific attenuation coefficient, $\mathrm{a}^{*}{ }_{440}$. All samples and fractions of the July 1999 survey are included. The variables measured on the Altamaha large fraction sample (O) were excluded from the calculation of the regression line. The relationship of the 2 parameters in February 2000 was: $\mathrm{a}^{*}{ }_{440}=-69.034 * \mathrm{~S}+1.3, \mathrm{r}^{2}=$ $0.72, \mathrm{n}=22, \mathrm{p}<0.001$.

The higher average $\mathrm{a}^{*}{ }_{440}$ in July is apparently the result of the higher proportion of the large and medium fractions in the colored DOM than in February (Tab. 1). 
The high correlation between DOC concentration and specific absorption was seen in two separate surveys in this study, and is also known from other studies where DOC was dominated by colored substances (Vodacek et al. 1995; Laurion et al. 2000). Using measurements of the origin samples and all resulting fractions, we found a moderately high correlation between $\mathrm{S}$ and $\mathrm{a}^{*}{ }_{440}$ (Fig. 4). The relationship between those two parameters was nearly identical, in two separate surveys. It indicates that both the pattern of light absorption and its magnitude is dependent on molecular size distribution of DOC, and underlines that the optical characteristics of the yellow substance are an outcome of the additive influence of DOC components.

\section{ACKNOWLEDGMENTS}

Y.Z. Yacobi was supported in part by the University of Georgia Marine Institute Visiting Scientist Program and Miss McElvaine was supported by the University of Georgia Marine Institute Student Intern Program. This publication is contribution number 856 of the University of Georgia Marine Institute. We acknowledge the contribution of Drs. Ostrovsky, Gitelson, Eckert, and two anonymous reviewers who reviewed a previous version of the current manuscript.

\section{REFERENCES}

Alberts, J.J., J.P. Giesy \& D.W. Evans. 1984. Distribution of dissolved organic carbon and metal-binding capacity among ultrafilterable fractions isolated from selected surface waters of the southeastern United States. Environ. Geol. Water Sci., 62: 91-101.

Alberts, J.J., \& Z. Filip. 1994. Humic substances in rivers and estuaries of Georgia, USA. Trends in Chem. Geol., 1: 143-162.

Alberts, J.J \& C. Griffin. 1996. Formation of particulate organic carbon (POC) from dissolved organic carbon (DOC) in salt marsh estuaries of the southeastern United States. Arch. Hydrobiol. Spec. Issues Advan. Limnol., 47: 401-409.

Alexander, C.E., M.A. Broutman \& D.W. Field. 1986. An Inventory of Coastal Wetlands of the USA. NOAA, U.S. Dept. Commerce, Washington, DC.

Benner., R., \& J.I. Hedges. 1993. A test of the accuracy of freshwater DOC measurements by high-temperature catalytic oxidation and UV-promoted persulfate oxidation. Mar. Chem., 41: 161-165.

Blough, N.V., O.C. Zarifiou \& J. Bonnila. 1993. Optical absorption spectra of waters from the Orinoco river outflow: terrestrial input of colored organic matter to the Carribean. J. Geophys. Res., 98: 2271-2278.
Bricaud., A., A. Morel \& L. Prieur. 1981. Absorption by dissolved organic matter of the sea (yellow substance) in the UV and visible domains. Limnol. Oceanogr., 26: 43-53.

Carder, K.L., R.G. Steward, G.R. Harvey \& P.B. Ortner. 1989. Marine humic and fulvic acids: Their effects on remote sensing of ocean chlorophyll. Limnol. Oceanogr., 34: 68-81.

Davis-Colley, R.J., \& W.N. Vant. 1987. Absorption of light by yellow substance in freshwater lakes. Limnol. Oceanogr., 32: 416-425.

De Haan, H., \& T. de Boer. 1986. Geochemical aspects of aqueous iron, phosphorus and dissolved organic carbon in the humic Lake Tjeukemeer, The Netherlands. Freshwat. Biol., 16: 661-672.

Dekker, A.G. 1993. Detection of the Optical Water Quality Parameters for Eutrophic Waters by High Resolution Remote Sensing. Ph.D. Thesis, Free University, Amsterdam, The Netherlands.

Ferrari, G.M., \& M.D. Dowell. 1998. CDOM absorption characteristics with relation to fluorescence and salinity in coastal areas of the Southern Baltic Sea. Estuar. Coast. Shelf Sci., 47: 91-105.

Green, S.A., \& N.V. Blough. 1994. Optical absorption and fluorescence properties of chromophoric dissolved organic matter in natural waters. Limnol. Oceanogr., 39: 1903-1916.

Kalle, K. 1966. The problem of Gelbstoff in the sea. Oceanogr. Mar. Biol. Annu. Rev., 4: 91-104.

Kirk, J.T.O. 1994. Light \& Photosynthesis in Aquatic Ecosystems. Cambridge University Press, Cambridge.

Laurion, I., M. Ventura, J. Catalan, R. Psenner \& R. Sommaruga. 2000. Attenuation of ultraviolet radiation in mountain lakes: factors controlling the among- and within-lake variability. Limnol. Oceanogr., 45: 1274-1288.

Mopper, D.P., Z. Feng, S.B. Bentjen \& R.F. Chen. 1996. Effects of cross-filtration on the absorption and fluorescence properties of seawater. Mar. Chem., 55: 53-74.

NOAA. 1985. National Estuarine Inventory Data Atlas. U.S. Dept. Commerce, Washington, DC.

Obernosterer, I., R. Sempere \& G.J. Herndl. 2001. Ultraviolet radiation induces a reversal of the bioavailability of DOM to marine bacterioplankton. Aquat. Microb. Ecol., 24: 632-643.

Stedmon, C.A., S. Markager \& S. Kass. 2000. Optical properties and signatures of chromophoric dissolved organic matter (CDOM) in Danish coastal waters. Estuar. Coast. Shelf Sci., 51: 267-278.

Visser, S.A. 1984. Seasonal changes in the concentration and colour of humic substances in some aquatic environments. Freshwat. Biol., 14: 79-87.

Vodacek, A., F.E. Hoge, R.N. Swift, J.K. Yungel, E.T. Peltzer $\&$ N.V. Blough. 1995. The use of in situ and airborne fluorescence measurements to determine UV absorption coefficients and DOC concentrations in surface waters. Limnol. Oceanogr., 40: 411-415.

Zepp, R.G. \& P.F. Schlotzhauer. 1981. Comparison of photochemical behavior of various humic substances in water. III. Spectroscopic properties of humic substances. Chemosphere, 10: 479-486. 